DOSSIÊ TEMÁTICO: Formação inicial de professores em contextos escolares e binômio teoria/prática nos estágios supervisionados

do/ https://doi.org/10.22481/rpe.v16i43.6929

\title{
ENSINANDO A ENSINAR: DIRETRIZES E ESTRATÉGIAS PARA MELHORAR A FORMAÇÃO DE PROFESSORES NO ENSINO SUPERIOR
}

\author{
TEACHING TO TEACH: GUIDELINES AND STRATEGIES TO IMPROVE TEACHER \\ TRAINING IN HIGHER EDUCATION
}

\begin{abstract}
ENSEÑAR A ENSEÑAR: DIRECTRICES Y ESTRATEGIAS PARA MEJORAR LA FORMACIÓN DE PROFESORES EN LA EDUCACIÓN SUPERIOR
\end{abstract}

\author{
Cosimo Laneve \\ University of Bari - Italy \\ Rosatilde Margiotta \\ University of Bari - Italy
}

Resumo: O debate sobre a qualidade da formação de professores universitários é mais do que nunca uma questão relevante. É um tópico que frequentemente aparece em periódicos especializados sobre ensino superior frequentemente examinado no contexto científico. Este artigo aborda algumas dessas questões complexas e as ilustra com exemplos retirados de um estudo da Universidade de Bari.

Palavras-chave: Formação de professores; Ensino superior; Ensino centrado no estudante.

Abstract: The debate on the quality of university teacher education is more than ever a relevant issue. It is a topic which frequently appears in specialized journals about Higher Education and is often examined in a scientific context. This article takes up some of these complicated issues and illustrates with examples taken from a study at the University of Bari.

Key words: Teacher training; Higher education; Student-centred learning,

Resumem: El debate sobre la calidad de la formación del profesorado universitario es más que nunca un tema relevante. Es un tema que a menudo aparece en revistas especializadas sobre educación superior que a menudo se examinan en el contexto científico. Este artículo aborda algunos de estos problemas complejos y los ilustra con ejemplos de un estudio realizado por la Universidad de Bari. 
Palabras clave: Formación de profesores; Enseñanza superior; Enseñanza centrada en el alumno.

The information gathered initially regarding quality has generally focused on quality assessment: students results are systematically evaluated by a central state organism applying national standards and using standard criteria to evaluate impact learning.

Traditionally university systems have paid a lot of attention to this method of quality assessment which has been usual method since the early 80s. Nowadays in Europe there are several assessment models of teaching processes, and each one differs in its cultural and political traditions. However, the most widespread one is the model which empowers the organizational guidelines of University systems and regulates the legislative development of curricula, programming courses and exams.

Thanks to feedback from the British, French and Dutch, the more recent methods of quality control have been applied by the periodical inspection of activity by the universities' central administration. The current British university system can be taken into consideration as, on the one hand, the self-evaluation of the institutions prepares the value judgment for auditor experts who are external; while on the other hand, it manages the awkward mechanisms of public funding allocation. It can be defined as a two-phase and well-tested system (e.g. self-evaluation and independent external evaluation) which prompts other European countries to adopt similar solutions (ENTWISTLE; TAIT, 1990).

Making a brief reference to the Italian system, it can be said that the larger decisional autonomy granted to our universities is counterbalance (cf. Law n.537/93) to the evaluation organisations at the national level (the observatory/osservatorio) and for each individual university (evaluation units/nuclei di valutazione). These organisations also deal with quality control as article 5 states: "[they will assess] the productivity of research and teaching".

In the light of these premises, the question arises as to how a university system of "quality" can be truly defined.

In its broader sense, "quality" is one which advocates ambitious objectives and frequently pays attention to teaching methodologies and learning styles (DEBRY; LECLERCQ; BOXIJS, 1998). Briefly, this type of teaching model aims to achieve its own objectives in an effective and efficient way and to be fulfilling for both teachers and students. The combination of effectiveness and efficiency can lead to reduce excess and idle costs by enhancing the fulfilment of the user's expectations. All this means is the need to define an 
innovative way of intervening in both the academic research and teaching processes (TRIGWELL; MARTIN, 2003).

From this perspective, it is essential to identify the specific objectives in order to have a clear understanding of "how" and "what" needs to be improved; especially nowadays there is a need to establish some requirements functional to teacher training.

Besides field and teaching knowledge, a teacher is required to be thoughtful, critical, ethically responsible. A teacher should be dynamic, take initiative, be a good planner and be a long life-learner.

Teaching methodology which should adopt different modalities and plural mediators (e.g. a clear definition of personalized and challenging learning strategies; frequent use of research-based methods; focusing on discussion as a very fruitful moment functional to the "interpretative negotiation"). This methodology clearly implies the reshaping of the hegemonic view of teaching. The latter, which is a common characteristic in several university systems, usually is the cause of a passive attitude in the student, since it does not enable the student to develop such abilities and skills as those above mentioned (CARRE; MOISAN, 2002). In fact, it is well known that when we teach message, we deliver both the content and the medium or the media used to create it. Thus, it means that we use medium both a tool and as a subject matter, that is our own teaching method and view.

Taking this into account, the teacher must lead the student to learn and assess how much importance and influence the teaching methods can have on what he/she effectively learns (LE BOTERF, 2000). And all this is particularly relevant for future teachers who will be able to reproduce in their own teaching experience the same methods and contents they have learnt throughout.

These assumptions emerge from experience and from theoretical study which have contributed to define the following key-points: objectives, choice of topics, materials, study methods and procedures, timetables, curriculum structures (LENOIR; LIPIANSKY, 2003). As far as this study is concerned, the aim is to outline more and more effective teaching methods.

Initial assumptions are mainly based on the action of teaching which does not directly produce positive learning effects. Teaching is an intentional action aiming to promote the learning of fruitful knowledge, abilities and skills in a systematic way. In fact, it can only create the conditions which can optimize the student's action of learning in a way advocated 
by the teacher. Furthermore, this action has also the objective of effective communication as a means of negotiation in student-teacher interactions.

Teaching is implemented to create conditions in order to optimise the student's learning process following to the teacher's directions. The theoretical study alone is not sufficient for a teacher to comprehend the complexity of their role. Teachers find themselves in very different and often unpredictable situations. Teacher's know-how enables his/her to relate to a specific teaching context (LANEVE, 2005a). Both theory (teaching research) and practice (planning, stimulations, etc.) have contributed to trace guide lines and to focus on the quality of teaching offered which perfectly combines both aspects.

In synthesis, it is necessary that didactic action completes the application of theoretical planning (didactic research) together with the practical one (project, simulation, etc.) (HATIVA; RAVIV, 1996).

From the theoretical research the attention should be focus towards the context (emphasizing the interpretative function), to didactic theory and to the guidelines applied in higher education.

To integrate the theoretical part with practice it could be useful to organise interdisciplinary seminars (interpretative function) about: educational evaluation; history; history of pedagogy; pedagogy; comparation education; theory of education; curriculum development; simulation, lesson.

Several methods can be used other than seminars or the traditional lecture method, for example group activities (BENJAMN, 2001; STERNBERG, 2003): debate classrooms; negotiations; case analysis; research (bibliography, study, solutions, control); problemsolving; reflection on student's experiences.

Practical planning requires instead that action is articulated on: content; training; observation.

The methods for the practical part are very different: seminars; action-research; teaching contact; laboratories; simulation; films; use of teaching technologies.

The principles on which the teaching is based on can be summarized as follows (TRIGWELL; PROSSER, 1999): enhancing the student's active role defining his/her starting competences, research and study experiences, as well as teaching and work experiences, developed in Italy or in foreign country. How student learning is not only related to memorization skills, but it is based on notes taking and books using (e.g. he/she reads, 
underlines and/or photocopies them). It is also based on the files stored in his/her database, by the people he/she can ask for advice, information or an explanation.

All these points form what is known as "distributed cognition": assuring high scientific quality by means of both theory and practice; offering modular courses as a "package" within a six-month term (SCHRAW, 2000); prompting the university's interventions (e.g. recognition of previous study or of teaching work developed in other areas) in the field of "permanent education"; assuring the student's right to correct and clear evaluation defining evaluation criteria and types of assessment (ECCLES; WIGFIELD, 2000); applying a style of teaching which draws on the espirt expérimental model and aims to test the following points: a) new teaching methods which can make the teaching-learning process even more worthwhile; b) new forms of study and attendance at evening classes; c) different study techniques which adopt open learning teaching methods; d) organizing course schedule (due dates); e) defining timing of exams (pre-test, partial or total tests); f) use of decentralized teaching structures (cf. DPR 382/1980, article 92 which states the permitted fields of experimental teaching).

Methodology consists of: unveiling the suggested pathway and emphasizing the value of educational expertise; using, enhancing and activating the plurality of cultural mediators (e.g. lectures, exercises, seminars, research groups and workshops, etc.) in order to respect the cognitive levels of students coming from different secondary schools and to enhance other types of intelligence (i.e. different formae mentis) (ARONSON, 2002); using teaching modules. The concept of the school module is often ambiguous. A module is not a mere periodic teaching-learning unit, but a "piece" of a sequence that can be combined either with other pieces of the same sequence or in isolation with different learning effects; offering supporting material for study and avoiding monolithic pathways (SCHUNK, 2000); planning teaching interactive situations which can allow the student to express his/her personal options by comparing them with scientific theories; organizing frequent situations of teaching contact, so that part of the student's learning which is not based on individual study (i.e. work load), but it is based on educational experiences organised by the teacher (VOLET; JÄRVELÄ, 2001); aiming for multidisciplinary (e.g. combining with other courses and exams) and interdisciplinary (e.g. seminars) organization which becomes the means to promote integrated models of teaching and evaluation; adopting student teaching credits and planning the following activities: a) full time courses (e.g. eight consecutive hours at week and twice or three times a term); b) attending residential seminars abroad (e.g. 36-40 hours in 6-8 days as 
arranged, for instance, in the ERASMUS project), meetings and so on; c) evening classes for students who are also part-times workers in order to allow them to organize their courses and exams in a more flexible way than the official university timetables; d) traditional seminars (2 hours a week for 8-10 weeks); e) field study followed by a final report which corresponds to a fourth of the term; f) educational trips and visits followed by a final report which corresponds to a fourth term; g) integrative courses; h) distance learning courses.

The student's right to study is one of the most effective criteria in the definition of adequate pathways functional to personalized and stimulating cultural projects. However, they strongly require the student's involvement, presence and study (DONALD, 1994). To this end, it is clearly necessary to elaborate such effective devices to achieve the right to study as those which are listed below.

As for those students who cannot attend the university courses the following alternatives are outlined: new educational methods in order to make more fruitful the teaching and learning process; new forms of study and attendance at university through evening classes; different study approaches thanks to open learning strategies; the fulfilment of open archives; modular organization; workshops; promotion of the tutorial service.

Evaluation is no longer the tool of strict selection any more, but it can be considerate the mode to promote (as Latin etymology of the word strongly marks: pro-movere, "to carry on", “to go further").

The educational function of evaluation is to be clarified: it is known as the feed-back or the regulation function (BONNIOL; VIAL, 1997). It is based on principle borrowed from cybernetics and applied to teaching fields which provides that information sequences of an in progress-process in order to allow the immediate shaping and reshaping-of the educational proposal (BOEKAERTS; PINTRICH; ZEIDNER, 2000): written tests with open-answer questions; written reports; simulations of real teaching practice; group discussion; test planned in a work context; training projects; preordained discussions; lesson summaries; essays on a given topic; practical tests (technical, graphic and planning) and talks.

The introduction of an educational contract would allow the student to design and define a personal syllabus of the courses which best combine his/her own interests, previous study experiences and future aspirations.

This paper suggests considering that effective teacher training requires the integration of theoretical knowledge with practical skills, use of methodologies and strategies (problem solving, practical training) capable of actively involving students in their learning. Permitting 
future teachers to experiment innovative and student-centred forms of learning are crucial elements for the entire educational pathway: trainee teachers are thus able to carry out teaching activities capable of developing authentic student growth.

\section{BIBLIOGRAPHY}

ARONSON, J. (ed.), Improving Academic Achievement. Impact of Psychological Factors on Education, Academic Press, San Diego (CA) 2002.

BENJAMN, J. What University Teachers Teach and How Do They Teach It? in Hativa N., Goodyear P. (eds), Teacher Thinking, Beliefs and Knowledge in Higher Education, Kluwer Academic Publisher, Dordrecht 2001.

BOEKAERTS, M.; PINTRICH P.R.; ZEIDNER, M. (eds.), Handbook of Self-Regulation, Academic Press, San Diego (CA) 2000.

BONNIOL, J. J.; VIAL, M., Les modéles de l'évaluation, De Boeck-Larcier, Bruxelles 1997.

CARRE, P. MOISAN, A. La formation autodirigée: Aspects psychologiques et pédagogiques, L'Harmattan, Paris 2002.

DEBRY, M.; LECLERCQ, D.; BOXIJS, E. De nouveaux défies pour la pédagogie universitaire, in Leclercq D., Pour une pédagogie universitaire de qualité, Mardaga, Sprimont (Belgique) 1998.

DONALD, J.G. Science Student's Learning Ethnographic Studies in Three Disciplines, in Pintrich P.R, Brown D.R., Weinstein C.E. (eds.), Student Motivation, Cognition and Learning, Lawrence Erlbaum Associates Pubhlishers, Hillsdale (NJ) 1994.

ECCLES, J.S.; WIGFIELD A. (ed.). Development of Achievement Motivation, Academic Press, San Diego (CA), 2002.

ENTWISTLE, N.; TAIT, H. Approaches to Learning, Evaluation of Teaching and Preferences for Contrasting Academic Environments, in "Higher Education", n. 19, 1990.

HATIVA, N. RAVIV, A. University Instructors' Ratings Profiles: Stability over Time, and Disciplinary Differences, in «Research in Higher Education», 37 (3), 1996.

LANEVE, C. Du banc de l'école a' la chaire du professeur. Le role de la memoire dans le métier d'enseignant, Séminaire Open, Paris, Les 2 et 3 Juin 2005.

LANEVE, C. Training is the Topos which Encompasses All the Complexity of the Research in the Field of Teaching in 29th Annual Conference "Teacher Education between Theory and Practice", ATEE (Association for Teacher Education in Europe), Agrigento 23-27 October 2005. 
LE BOTERF, G. Construire les compétences individuelles et collettives, Éditions d'Organisation, Paris 2000.

LENOIR, H.; LIPIANSKY, E. M. Recherches et innovations en formation, L'Harmattan, Paris 2003.

SCHRAW, G. (ed.). Metacognitive Assessment, University of Nebraska Press, Lincoln, 2000.

SCHUNK D.H., Learning Theories: An Educational Perspectives, 3 rd, Upper Saddle River, NJ, Merrill/Prentice Hall 2000.

STERnBERG, R. J. (e.d.). The Psychology of Problem Solving, Cambridge University Press, Cambridge 2003.

TRIGWELL, K.; MARTIN, E. Qualitative Differences in University Teaching, in Tight M. (ed), Access and Exclusion, JAI Elsevier, Oxford 2003.

TRIGWELL, K.; PROSSER, M. Understanding Learning and Teaching: The Experience in Higher Education, Open University Press, Buckingham 1999.

VOLET, S., JÄRVELÄ, S. (eds.). Motivation in Learning Contexts: Theoretical Advances and Methodological Implications, Pergamon, Amsterdam 2001.

\section{ABOUT THE AUTHORS:}

\section{Cosimo Laneve}

Former director of the Department of Education at the University of Bari and former director of the Ionic Department of Legal and Economic Systems of the Mediterranean: Society, Environment, Culture of University of Bari. He was the president of the Italian Society of Pedagogy (SIPED) from 2003 to 2006. Professor Laneve is the only Italian member of the International Study Association on Teachers and Teaching (ISATT).

He is the author of 800 publications and editor-in-chief of the journal Quaderni di Didattica della Scrittura. E-mail: minonix@ libero.it

(iD http://orcid.org/0000-0002-7441-4754

\section{Rosatilde Margiotta}

$\mathrm{PhD}$ student in pedagogy in the Ionic Department of Legal and Economic Systems of the Mediterranean: Society, Environment, Culture at the University of Bari in Taranto. Her research interests concern innovations in education, with a focus on technology-enhanced learning and improvement of teacher training following a narrative-inquiry approach. She is the author of several papers and publications about her research results. E-mail: rosatilde.margiotta@uniba.it

iD http://orcid.org/0000-0002-6185-3563

Recebido em: 18 de abril de 2020

Aprovado em: 19 de agosto de 2020 Publicado em: 01 de dezembro de 2020 